\title{
Research and Analysis of Firm Performance Evaluation in Eco-Industrial Park
}

\author{
Ling-ling LUO \\ School of Mathematics and Statistics, \\ Guizhou University of Finance and Economics, Guizhou, China
}

Keywords: Firm Performance; AHP; FAHP.

\begin{abstract}
Starting from the three aspects of material input, utilization and output, the paper establishes a firm performance evaluation index system including enterprise strength, enterprise efficiency, social environmental impact, four dimensions of enterprise development potential and 18 secondary evaluation indicators. Based on the statistic data of firm in Guizhou E Eco-Industrial Park in 2016, the paper evaluates the performance of firm by FAHP method. Research shows that the higher the social satisfaction index, the greater the development potential of firm, and also the faster the development of Eco-industrial park.
\end{abstract}

\section{Introduction}

Under the background of the rapid development of large data, the development of eco-industrial park enterprises has become an important research direction in the field of industrial ecology and economy. Eco-industrial Park is a new type of industrial park which combines the economic concept of production, consumption demand, cyclic sustainable development and industrial principles. The circular structure of "production-distribution-consumption-decomposition" in its industrial chain is to construct a network of energy-dynamic Conservation Industrial chain, form a mutually beneficial industrial ecosystem, maximize resource operation, minimize waste formation, optimize economic benefits, and achieve sustainable economic, social and environmental development. Therefore, in the process of large-scale ecological park construction, we should explore how to effectively introduce the development of Park enterprises, how to effectively evaluate the construction of Park enterprises, realize the combination of economic and social benefits of industry, realize the sustainable development of industry, ensure a good ecological environment and optimize the construction of ecological civilization. It played an important role.

At present, researchers at home and abroad have launched a lot of discussions on the selection and evaluation of enterprise performance indicators in eco-industrial parks. Frosch and Gallopoulos [1] propose industrial Ecology. Korhonen [2], Gibbs and Deutz [3] expound the characteristics and structure of industrial ecosystem from different aspects, which laid a foundation for the study of eco-industrial park. Kaplan and Norton [4] use the balanced scorecard to evaluate enterprise performance. $\mathrm{Qu}$ and Cooper [5] use a multidimensional perspective to construct Balanced Scorecard performance indicators in enterprise management. Wenbo [6] construct the evaluation index system of eco-industrial park from five aspects: elements, environment, economy, society and management. Ronald W.M.,et al. [7] examine the benefits and costs associated with foreign independent directors (FIDs) at U.S. corporations and find that firms with FIDs make better cross-border acquisitions when the targets are from the home regions of FIDs. Dursun D., et al. use four popular decision tree algorithms (CHAID, C5.0, QUEST and C\&RT) to investigate the impact of financial ratios on firm performance [8]. Bai C., et al. introduces the use of Fuzzy C-Means and TOPSIS for organizational performance evaluation purposes [9]. Using real company data and balanced scorecard accounting and performance dimensions the methodology is applied and evaluated.

This paper applies the basic idea of the balanced scorecard, and establishes the evaluation index system from the perspective of the enterprise performance of the eco-industrial park. Then it uses the fuzzy analytic hierarchy process (FAHP) comprehensive evaluation method to evaluate the enterprise performance, so as it provide help for the enterprise performance evaluation and 
optimization.

\section{Establishment of Enterprise Performance Evaluation Index}

On the basis of large data platform, the management methods such as ecological law, economic law and system engineering are used to realize resource saving, waste recycling and pollution control in the eco-industrial park. So it is very important to realize the harmonious, stable and sustainable development of the eco-industrial park.

This paper adds the corresponding performance evaluation index through literature analysis, and tests the equilibrium of the overall framework of the index. Therefore, in the performance evaluation system of eco-industrial park enterprises, we select four dimensions: enterprise strength, enterprise efficiency, social environmental impact, enterprise development potential.

Enterprise strength index which is to evaluate the ability of eco-industrial park enterprises to meet the market is an important indicator of sustainable development of enterprises. Enterprise efficiency is to evaluate the ability of eco-industrial park enterprises to use the assets under control to produce economic benefits. At the same time, five secondary indicators such as growth rate, output rate, labor productivity, per capita income are selected to quantify. The index of social environmental impact is to evaluate the environmental impact of wastes produced in production activities. The index of enterprise development potential is a hidden index to evaluate the sustained and stable development of enterprises. The index system is divided into target (decision) level, criterion level and index level, as shown in Table 1.

Table 1. Index System of Enterprise Performance Evaluation

\begin{tabular}{|c|c|c|}
\hline target level & criterion level & index level \\
\hline \multirow{18}{*}{$\begin{array}{l}\text { Eco-industrial park } \\
\text { performance } \\
\text { indicators }\end{array}$} & \multirow{3}{*}{ enterprise strength } & total investment \\
\hline & & annual output value \\
\hline & & number of employees \\
\hline & \multirow{6}{*}{ enterprise efficiency } & growth rate \\
\hline & & Capital output rate \\
\hline & & Land yield \\
\hline & & labour productivity \\
\hline & & per capita income \\
\hline & & capital turnover cycle \\
\hline & \multirow{6}{*}{ social environmental impact } & Annual tax revenue \\
\hline & & new employability \\
\hline & & industrial driving force \\
\hline & & foreign exchange-earning \\
\hline & & GDP energy intensity \\
\hline & & environmental compliance rate \\
\hline & \multirow{3}{*}{$\begin{array}{l}\text { enterprise development } \\
\text { potential }\end{array}$} & proportion of R \& D investment \\
\hline & & patent authorization number \\
\hline & & number of famous brands \\
\hline
\end{tabular}

\section{Research Method}

\subsection{Analytic Hierarchy Process}

The Analytic Hierarchy Process (AHP) [10] is a theory of relative measurement with absolute scales of both tangible and intangible criteria. The decision-making elements are decomposed into objectives, criteria, indicators and other levels. AHP comprises of the following steps: first, Set up a multilevel hierarchical structure model; Second, Construct judgement matrix. According to the upper criterion, after comparing the elements belonging to the same level, the relative importance of 
the elements belonging to the same level is determined according to the criterion of judgment criterion. Set judgement matrix $A=\left(a_{i j}\right)_{n \times n}$, and $a_{i j}>0, a_{i j}=1 / a_{j i}, a_{i i}=1, i, j=1,2, \ldots, n$. The 1-9 scale type is used to assign the degree of importance, and the value of the judgment matrix reflects people's understanding of the relative importance of various factors. Third, the consistency test of judgement matrix. Definition $A x=\lambda x, \lambda$ is eigenvalues, for all $a_{i i}=1, \sum \lambda_{i}=n$. $C I=\left(\lambda_{\max }-n\right) /(n-1)$ is an index to judge the deviation of judgment matrix: the greater the CI value, the greater the degree of deviation of the judgment matrix from the complete consistency, the smaller the CI value, the better the consistency of the judgement matrix. By querying the random consistency index table RI, we can calculate the random consistency ratio: $C R=C I / R I$. If $C R \leq 0.1$, the judgement matrix has satisfactory consistency, otherwise, it is not satisfied, then the judgment matrix need to readjust so that it is close to satisfactory consistency. Finally, Calculate combined weights.

The weighting coefficients of each level of the evaluation index system to the overall objective are calculated, and then we can get the key factors which are used to construct the optimal strategic selection hierarchical model.

\subsection{Fuzzy Analytic Hierarchy Process}

A fuzzy Analytic Hierarchy Process is applied as an evaluation technique. Laarhoven et al. [11] is the first time to put the analytic hierarchy process into fuzzification. Buckley [12] develop a comprehensive evaluation method that is fuzzy analytic hierarchy process (FHAP). FHAP can effectively deal with the subjective and objective fuzzy phenomena in the evaluation process. FAHP comprises of the following steps:

First, set up a set of evaluation factors $A=\left\{a_{1}, a_{2}, \ldots, a_{N}\right\}, a_{i}$ a evaluation factor, $\mathrm{N}$ is the number of factors on the same level.

Second, establish a set of criteria for evaluating grades $B=\left\{b_{1}, b_{2}, \ldots, b_{n}\right\}, b_{j}$ is a criteria for evaluation.

Finally, build the relative subordinate degree matrix. Suppose $a_{i}$ is evaluated by single factor, and then we can get a fuzzy vector $C_{i}$ relative to $b_{j}, C_{i}=\left(c_{i 1}, c_{i 2}, \ldots, c_{i j}\right), i=1,2, \ldots, N, j=1,2, \ldots, n$. $c_{i j}$ is a factor about $a_{i}$ and $b_{i}$.According to the principle of maximum membership, the evaluation grade of the evaluation object is determined, and the evaluation result is finally given.

\section{Application of FAHP Method}

AHP method is used to establish the index system of enterprise development, and then the fuzzy comprehensive evaluation method is used to establish a four-dimensional factor model including enterprise strength, enterprise efficiency, social environmental impact, enterprise development potential. This paper chooses the impact indicators of enterprise development in Guizhou E Industrial Park, and establishes an AHP model of enterprise development evaluation.

\subsection{Construction of Pairwise Comparison Matrices}

According to Table 1, the pairwise comparison matrices of enterprise strength, enterprise efficiency, social environmental impact, enterprise development potential are structured. By using the 1-9 scale method, we determine each judgment matrix and its eigenvectors, as show from table 2 to table 6.

According to the table 2, the corresponding weight values of enterprise strength, enterprise efficiency, social environment impact degree and development potential are 0.593, 0.0675, 0.2147 and 0.1248 respectively. It can be seen from table 3 that the annual average output value of enterprises which is 0.487 is larger in the evaluation of enterprise strength. In the process of production efficiency evaluation in table 4, the growth rate of enterprises accounts for a larger proportion of all indicators. The value is 0.371 . Among the social environmental impact assessment indicators in table 5 , the ratio of environmental compliance rate in all indicators is 0.3585 , which shows that the environmental compliance rate plays a major role in the social environmental impact 
assessment. In table 6 , the index weight of patent authorization number is 0.6716 in the process of evaluating the development potential of enterprises, indicating that the proportion of patent authorization number is the largest.

Table 2. The Judgement Matrix and Weight of Each Index Based on the Evaluation of Enterprise Development

\begin{tabular}{l|l|l|l|l|l}
\hline $\begin{array}{l}\text { Evaluation of enterprise } \\
\text { development }\end{array}$ & strength & $\begin{array}{l}\text { efficienc } \\
\text { y }\end{array}$ & $\begin{array}{l}\text { social environmental } \\
\text { impact }\end{array}$ & $\begin{array}{l}\text { developmen } \\
\text { t potential }\end{array}$ & weight \\
\hline strength & 1 & 7 & 5 & 3 & 0.593 \\
\hline efficiency & 0.1429 & 1 & 0.3333 & 5 & 0.0675 \\
\hline $\begin{array}{l}\text { social environmental } \\
\text { impact }\end{array}$ & 0.2 & 3 & 1 & 3 & 0.2147 \\
\hline development potential & 0.3333 & 2 & 0.3333 & 1 & 0.1248 \\
\hline
\end{tabular}

Table 3. The Judgement Matrix and Weight of Each Index Based on Enterprise Strength

\begin{tabular}{l|l|l|l|l}
\hline $\begin{array}{l}\text { Evaluation of enterprise } \\
\text { strength }\end{array}$ & $\begin{array}{l}\text { total } \\
\text { investment }\end{array}$ & $\begin{array}{l}\text { annual output } \\
\text { value }\end{array}$ & $\begin{array}{l}\text { number of } \\
\text { employees }\end{array}$ & weight \\
\hline total investment & 1 & 1 & 5 & 0.4353 \\
\hline annual output value & 1 & 1 & 7 & 0.4870 \\
\hline number of employees & 0.2 & 0.1429 & 1 & 0.0778 \\
\hline
\end{tabular}

Table 4. The Judgement Matrix and Weight of Each Index Based on Enterprise Efficiency

\begin{tabular}{l|l|l|l|l|l|l|l}
\hline enterprise efficiency & $\begin{array}{l}\text { growt } \\
\text { h rate }\end{array}$ & $\begin{array}{l}\text { Capital } \\
\text { output } \\
\text { rate }\end{array}$ & $\begin{array}{l}\text { Land } \\
\text { yield }\end{array}$ & $\begin{array}{l}\text { labour } \\
\text { producti } \\
\text { vity }\end{array}$ & $\begin{array}{l}\text { per } \\
\text { capita } \\
\text { income }\end{array}$ & $\begin{array}{l}\text { capital } \\
\text { turnover } \\
\text { cycle }\end{array}$ & weight \\
\hline growth rate & 1 & 7 & 5 & 5 & 6 & 1 & 0.371 \\
\hline $\begin{array}{l}\text { Capital output } \\
\text { rate }\end{array}$ & 0.1429 & 1 & 5 & 2 & 3 & 0.1429 & 0.111 \\
\hline Land yield & 0.2 & 0.2 & 1 & 0.2 & 1 & 0.125 & 0.036 \\
\hline labour productivity & 0.2 & 0.5 & 5 & 1 & 3 & 0.5 & 0.1075 \\
\hline per capita income & 0.1667 & 0.333 & 1 & 0.333 & 1 & 0.2 & 0.0423 \\
\hline capital turnover cycle & 1 & 7 & 8 & 2 & 5 & 1 & 0.3322 \\
\hline
\end{tabular}

Table 5. The Judgement Matrix and Weight of Each Index Based on Social Environmental Impact

\begin{tabular}{l|l|l|l|l|l|l|l}
\hline & $\begin{array}{l}\text { annu } \\
\text { al } \\
\text { social environmental } \\
\text { tax } \\
\text { reve } \\
\text { nue }\end{array}$ & $\begin{array}{l}\text { new } \\
\text { employa } \\
\text { bility }\end{array}$ & $\begin{array}{l}\text { industri } \\
\text { al } \\
\text { driving } \\
\text { force }\end{array}$ & $\begin{array}{l}\text { foreign } \\
\text { exchang } \\
\text { e-earnin } \\
\text { g }\end{array}$ & $\begin{array}{l}\text { GDP } \\
\text { energy } \\
\text { intensit } \\
\text { y }\end{array}$ & $\begin{array}{l}\text { environm } \\
\text { ental } \\
\text { complian } \\
\text { ce rate }\end{array}$ & weight \\
\hline annual tax revenue & 1 & 0.1111 & 0.1429 & 2 & 0.2 & 0.2 & 0.0376 \\
\hline new employability & 9 & 1 & 1 & 9 & 7 & 1 & 0.3103 \\
\hline industrial driving force & 7 & 1 & 1 & 5 & 2 & 0.3333 & 0.1815 \\
\hline $\begin{array}{l}\text { foreign } \\
\text { exchange-earning }\end{array}$ & 0.5 & 0.1111 & 0.2 & 1 & 0.3333 & 0.1429 & 0.0303 \\
\hline GDP energy intensity & 5 & 0.1429 & 0.5 & 3 & 1 & 0.1111 & 0.0817 \\
\hline $\begin{array}{l}\text { environmental } \\
\text { compliance rate }\end{array}$ & 5 & 1 & 3 & 7 & 9 & 1 & 0.3585 \\
\hline
\end{tabular}


Table 6. The Judgement Matrix and Weight of Each Index Based on Enterprise Development Potential

\begin{tabular}{l|l|l|l|l}
\hline $\begin{array}{l}\text { Enterprise } \\
\text { Development potential }\end{array}$ & $\begin{array}{l}\text { Proportion } \\
\text { of R \& D } \\
\text { investment }\end{array}$ & $\begin{array}{l}\text { Patent } \\
\text { authorization } \\
\text { number }\end{array}$ & $\begin{array}{l}\text { number of } \\
\text { famous } \\
\text { brands }\end{array}$ & weight \\
\hline Proportion of R \& D investment & 1 & 0.1111 & 0.2 & 0.0629 \\
\hline Patent authorization number & 9 & 1 & 3 & 0.6716 \\
\hline number of famous brands & 5 & 0.3333 & 1 & 0.2654 \\
\hline
\end{tabular}

From the AHP method, the judgement matrix based on each index can be obtained. Then we can get the maximum eigen value and calculate the random consistency ratio CR. The results are shown as in Table 7. From the Table 7, it shows that all the $C R<0.1$ in the judgement matrix, so that we can see that the judgement matrix is consistent with the consistency test. so fuzzy comprehensive evaluation system can be carried out. Because $\mathrm{CR}=0.0121$ in Enterprise strength, it is an important index to judge the development of an enterprise.

Table 7. Consistency Test Results of Judgement Matrices

\begin{tabular}{l|l|l}
\hline matrix & $\lambda_{\max }$ & CR \\
\hline Judgment matrix based on the evaluation of enterprise development & 4.2391 & 0.0896 \\
\hline Judgement matrix based on the evaluation of enterprise strength & 3.0126 & 0.0121 \\
\hline Judgement matrix based on production efficiency evaluation & 6.6061 & 0.0675 \\
\hline Judgement matrix based on the evaluation of social environmental impact & 6.5530 & 0.0878 \\
\hline Judgement matrix based on evaluation of enterprise development potential & 3.0291 & 0.0279 \\
\hline
\end{tabular}

\subsection{The Use of FAHP Method}

A questionnaire survey was conducted to collect data. The set of evaluation factors is $\mathrm{A}=$ \{enterprise strength evaluation, production efficiency evaluation, social environmental impact evaluation, enterprise development potential evaluation $\}$. The grade $\mathrm{B}=\{$ satisfaction, good, general, dissatisfied $\}$.

The values of evaluation criteria were respectively satisfaction $=4$, good $=3$, general $=2$ and dissatisfied $=1$. According to the questionnaire survey, the following membership matrix is determined:

$$
C=\left[\begin{array}{llll}
0.7 & 0.1 & 0.1 & 0.1 \\
0.5 & 0.2 & 0.2 & 0.1 \\
0.4 & 0.3 & 0.1 & 0.2 \\
0.6 & 0.2 & 0.1 & 0.1
\end{array}\right]
$$

According to the AHP method, the weight of enterprise evaluation factors is obtained, and the enterprise strength evaluation is 0.593. Production efficiency evaluation is 0.0675 , social environmental impact evaluation is 0.2147 , and enterprise development potential evaluation is 0.1248 . The total score of the factor is:

$$
\begin{aligned}
& (0.593,0.0675,0.2147,0.1248)\left[\begin{array}{cccc}
0.7 & 0.1 & 0.1 & 0.1 \\
0.5 & 0.2 & 0.2 & 0.1 \\
0.4 & 0.3 & 0.1 & 0.2 \\
0.6 & 0.2 & 0.1 & 0.1
\end{array}\right] \\
& =(0.60961,0.16217,0.10675,0.12147)
\end{aligned}
$$

From the total score of the factors, we can see that the satisfaction is 0.60961 . According to the principle of maximum subordination, we can see that the evaluation of the enterprise is satisfactory. The enterprise can be used as the development goal of Guizhou Province. 


\section{Conclusion}

Eco-industrial park is an important practice form of industrial ecosystem. Some enterprises plan to effectively exchange materials and energy, and effectively share resources in order to build sustainable economic, social and ecological relations.

First, Based on the systematic perspective in the production process of eco-industrial park, 18 evaluation index system of two level evaluation index and four dimensions are established. From the AHP method, the results show that the weights of the four evaluation factors are different. The impact of enterprise strength on the performance of eco-industrial park enterprises is largest than other index. Finally, it shows that the strength of enterprises is an important factor affecting the overall ecological development level of Eco-industrial parks.

Second, FAHP comprehensive evaluation method is used to evaluate the enterprise performance of Guizhou E Enterprise Eco-industrial Park. Total score can be seen, satisfaction is 0.60961. According to the principle of maximum subordination, it is satisfied with the enterprise, and basically accords with the actual situation of the development of Guizhou Eco-Industrial Park enterprises. It shows that the evaluation index system established in this paper is reasonable.

Finally, the selected 18 eco-industrial parks can only reflect the development level of each factor, and do not represent the absolute quality of the development level of enterprises. On the issue of enterprise development, we should continue to increase the policy, financial and technical support to the enterprises of eco-industrial parks, develop the recycling technology of resources, enhance the strength of enterprises and improve the enterprise performance of eco-industrial parks, so as to achieve the coordinated and sustainable development of economy and resources.

\section{Acknowledgement}

The project is supported by Guizhou University of Finance and Economics in 2017.

\section{References}

[1] Frosch R.A., Gallopoulos N.E. Strategies for Manufacturing [J]. Scientific American. 1989, 261 (3): $144-152$.

[2] Korhonen J. Four Ecosystem Principles for an Industrial Ecosystem [J]. Journal of Cleaner Production, 2001, 9 (3): 253-259.

[3] Gibbs D., Deutz P. Reflections on Implementing Industrial Ecology Through Eco-industrial Park Development [J]. Journal of Cleaner Production, 2007, 15 (17): 1683-1695.

[4] Kaplan R S, Norton D P. The balanced scorecard--measures that drive performance [J]. Harvard Business Review, 1992, 70 (1): 71-79.

[5] Qu S.Q, Cooper D.J. The role of inscriptions in producing a balanced scorecard [J]. Accounting Organizations \& Society, 2011, 36 (6): 344-362.

[6] Wenbo L. Comprehensive evaluation research on circular economic performance of Eco-industrial parks [J]. Energy Procedia, 2011, 5: 1682-1688.

[7] Ronald W.M., Cong W. and Fei X. Globalizing the boardroom-The effects of foreign directors on corporate governance and firm performance [J]. Journal of Accounting and Economics, 2012, 53 (3): 527-554.

[8] Dursun D., Cemil K., and Ali U. Measuring firm performance using financial ratios: A decision tree approach [J]. Expert Systems with Applications, 2013, 40 (10): 3970-3983

[9] Bai C., Dileep D. and Joseph S. Integrating Fuzzy C-Means and TOPSIS for performance evaluation: An application and comparative analysis [J]. Expert Systems with Applications, 2014, 41 (9): 4186-4196. 
[10] Alexander, J. and Saaty, T. The forward and backward processes of conflict analysis [J], Behavioral Science, 1977, 22: 87-98.

[11] Laarhoven, V. and Pedrycz, W. A fuzzy extension of Salty's priority theory [J]. Fuzzy Sets and Systems, 1983, 11: 229-241.

[12] Buckley, J. Fuzzy hierarchical analysis [J]. Fuzzy Sets Systems, 1983, 3 (17): 233-247. 